\title{
JOHN OF DAMASCUS: REWRITING THE DIVISION OF HERESY AND SCHISM
}

St. John Damascene (ca. 650 - ca. 753) wrote several anti-heretical texts, the most famous of which is arguably his Liber de haeresibus. Traditionally

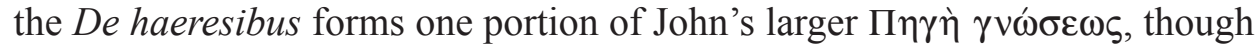
most of the De haeresibus was not his own composition. Much has been said about this collection of heresies and still much remains a mystery. Was such a catalogue of heresies intended to be, as Averil Cameron puts it,

"the equivalent of publishing a note in a learned journal, whose main claim to fame will be the number of entries in a future citation index?"1.

Are the chapters of De haeresibus meant as a means of separating the wheat from the chaff, orthodoxy from heterodoxy? Or is something else at work in this text? De haeresibus 81 against Nestorianism and 83 against Monophysitism obscure Damascenus' assessment of each. While he lists both as heresies to be rejected, he implies that there might be room for conciliation, especially between Monophysites and orthodox Christianity ${ }^{2}$. This attitude is best answered in conjunction with Damascenus' other writings against Nestorianism and Monophysitism. John Damascene penned five treatises criticizing Nestorianism and Monophysitism. Against the Monophysites he wrote the Contra Jacobitas, the Epistula de hymno trisagio, and the De natura composita sive Contra acephalos. Against the Nestorians he authored the De fide contra Nestorianos and Contra Nestorianos: the latter appears to be a revision of the former, written in dialogue form. Of these texts, the Contra Jacobitas and the

${ }^{*} \mathrm{PhD}$ Zachary M. Keith - Candidate in Historical Theology, School of Theology and Religious Studies, The Catholic University of America, Washington, DC; e-mail: 11keith@cua.edu.

${ }^{1}$ A. Cameron, How to Read Heresiology, "Journal of Medieval and Early Modern Studies" 33 (2003) 473.

2 John often refers to orthodox Christians, but he means Christians who accept Chalcedon's authority and teachings, which are typically labelled Melkites or perhaps even Byzantine Christians. I will use "mainstream" Christianity to refer to these in order to avoid confusion with John's other uses of orthodoxy and to avoid any possible confusion between Melkite and Byzantine Christians, but also because the acceptance of Chalcedon is part of the greater majority of Christianity in subsequent centuries. Cf. S. Griffith, "Melkites", "Jacobites", and the Christological Controversies in Arabic in Third/Ninth Century Syria, in: Syrian Christians Under Islam: The First Thousand Years, ed. D. Thomas, Leiden 2001, 11-38. 
Contra Nestorianos are the most valuable for deciphering Damascenus' attitude on each heresy ${ }^{3}$. My paper considers Damascenus' treatment of Nestorianism and Monophysitism in De haeresibus 81 and 83 in comparison with his writings in the Contra Jacobitas and the Contra Nestorianos. Through this comparison I argue that the ambiguity in the De haeresibus is not accidental; it is an intentional choice on Damascenus' part meant to highlight the ambiguous distinction between separation through schism and separation through heresy.

The first eighty chapters of the De haeresibus re-present the original 'Av $\alpha \kappa \varepsilon \varphi \alpha \lambda \alpha i \omega \sigma i s$ likely composed by Epiphanius around the fifth centu$\mathrm{ry}^{4}$. The eightieth chapter, on Messalianism, is augmented with descriptions of Messalian practices and statements from their works 5 . The final twenty chapters have an even more uncertain history, and hint at some relationship with the Doctrina Patrum. It is possible that Damascenus borrowed from the Doctrina Patrum, supplementing the catalogue with his own explanations, though a more likely account is that Damascenus' heresies were summarized and inserted into the Doctrina Patrum later ${ }^{6}$. A third possibility is that the Doctrina Patrum and the De haeresibus share a common source besides the 'Av $\alpha \kappa \varepsilon \varphi \alpha \lambda \alpha i \omega \sigma i s$, though such a text must have been lost. Regardless of their original source, these twenty chapters can certainly be described as John Damascene's addition to the project of cataloguing heresies. They reflect his genuine thought and cannot be dismissed simply as recapitulation of other texts. The chapters largely comprise heresies that arose after the Council of Ephesus as well as various disorganized heresies ${ }^{7}$. Damascenus addresses several Christological heresies in these chapters, among which are Nestorianism in chapter 81, Eutychianism in chapter 82, and Monophysitism in chapter 83.

${ }^{3}$ Andrew Louth (St. John Damascene: Tradition and Originality in Byzantine Theology, Oxford 2002, 155-173) lays out these texts and introduces their history. Louth concludes that the Contra Jacobitas is the most significant of the three anti-Monophysite texts, due to its length and general nature. Sidney Griffith (John of Damascus and the Church in Syria in the Umayyad Era: The Intellectual and Cultural Milieu of Orthodox Christians in the World of Islam, "Hugoye: Journal of Syriac Studies" 11:2008, fasc. 2, 217) explains that the Jacobites (Syrian Monophysites) and Nestorians leading into John's time were divided in their Christological beliefs, but united in their shared rejection of the Council of Chalcedon. These terms are not applied to the various groups according to beliefs alone, but often reflect ecclesial differences as well. I will use "Monophysite" throughout this paper, even when discussing Christians who properly speaking are not true Monophysites, following the language and attitude that John gives in his writings. Cf. S. Brock, The Syriac Churches and Dialogue with the Catholic Church, "Heythrop Journal" 45 (2004) 474 n. 1.

${ }^{4}$ Cf. O. Knorr, Zur Überlieferungsgeschichte des „Liber de haeresibus” des Johannes von Damaskus (um 650-vor 754): Anmerkungen zur Edition B. Kotters, ByZ 91 (1997) 59-69.

${ }^{5}$ Cameron (How to Read Heresiology, p. 475) suggests two possibilities for John's interest in Messalianism. First, Messalianism eventually came to be applied generically to heretics. Second, the Messalians had been mentioned in fifth-century councils and subsequently reiterated by Timothy of Constantinople during the seventh century.

${ }^{6}$ Cf. Louth, St. John Damascene, p. 54-55.

${ }^{7}$ Cf. ibidem, p. 59-60. 
Damascenus introduces the Nestorians as those people who

"teach that God the Word has its existence by itself and separately, and that his humanity exists by itself".

These Nestorians also deny that Christ's actions are performed together as by one and the same individual. Following the Nestorians in the De haeresibus are the Eutychians, who take their name and heresy from Eutyches ${ }^{9}$. According to John, the Eutychians were unable to explain how the Word united to himself the one responsible for Adam's sin, someone who happened to be a man. How could someone take upon himself the very things he would conquer? John's distinction of Eutychians in chapter 82 is significant insofar as John treats it separately from Monophysitism. In the controversy between Chalcedonian and non-Chalcedonian Christians, the overwhelming tendency in Chalcedonian Christianity has been to link the rejection of the Chalcedonian formula (among Christians who preferred Cyril's $\mu$ í $\alpha$ pvi $\sigma \varsigma \varsigma$ formula) with Eutychian Monophysitism $^{10}$. Aloys Grillmeier criticizes Pope St. Leo the Great for his inability to distinguish between the different parties who rejected the Council of Chalcedon. Grillmeier remarks that Timothy Aelurus, in spite of his rejection of Chalcedon, remained closer theologically to Chalcedon and Pope Leo than he was to Eutychianism, i.e. true Monophysitism ${ }^{11}$.

Chapter 83 is one of John's longest additions to the list of heresies: two important manuscript traditions of the De haeresibus even include a long excerpt taken from John Philophonus's Arbiter 4 and $7^{12}$. While Liber de haeresibus 81 and 82 are addressed to heretical factions, chapter 83 primarily confronts the "Egyptians", those who allegedly, because of the Tome of the Council of Chalcedon, "separated from the orthodox Church ( $\alpha \pi \circ \sigma \chi i \sigma \alpha \nu \tau \varepsilon \varsigma \tau \hat{\eta} \varsigma$ ỏ $\rho \circ \delta \delta$ ó $\xi o v$ $\dot{\varepsilon} \kappa \kappa \lambda \eta \sigma i \alpha \varsigma) " 13$. Apart from their new teaching, these Christians were "orthodox in every other way" 14 . Damascenus also speaks of these Egyptians as "those who are Monophysites and also $\Sigma \chi \eta \mu \alpha \tau \imath \kappa o$ " "15, since their heresy

${ }^{8}$ Johannes Damascenus, Liber de haeresibus 81, 1-2, ed. B. Kotter, in: Die Schriften des Johannes von Damaskos, vol. 4: Liber de haeresibus. Opera polemica, PTS 22, Berlin 1981, 48, transl. F.H. Chase, Jr.: Saint John of Damascus, Writings, The Fathers of the Church: A New Translation 37, Washington 1958, 138.

${ }^{9}$ Cf. ibidem 82, 1-9, PTS 22, 49, transl. Chase, p. 138.

${ }^{10}$ Cf. Sebastian Brock (The "Nestorian" Church: A Lamentable Misnomer, "Bulletin of the John Rylands Library" 78:1996, fasc. 2,27) for a helpful chart on the figures and teachings of these centuries.

${ }^{11}$ Cf. A. Grillmeier, Christ in Christian Tradition, vol. 2: From the Council of Chalcedon (451) to Gregory the Great (590-604), pt. 4: The Church of Alexandria with Nubia and Ethiopia after 451, transl. O.C. Dean, Jr., London 1996, 7-35.

${ }^{12}$ Cf. Johannes Damascenus, Liber de haeresibus 83, PTS 22, 50-55, transl. Chase, p. 140-148.

${ }^{13}$ Ibidem 83, 2-3, PTS 22, 49, transl. Chase, p. 138.

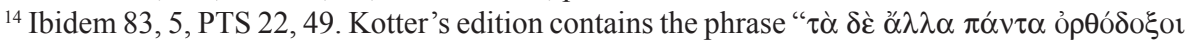
i $\alpha \dot{\rho} \rho \chi 0 \nu \tau \varepsilon \varsigma$ ". The English translation by Chase (Saint John of Damascus, Writings, p. 138-139) apparently omits this line, though it is found in PG 94, 741-742.

${ }^{15}$ Johannes Damascenus, Liber de haeresibus 83, 1, PTS 22, 49, transl. Chase, p. 138. 
arose in Alexandria, Egypt. As Kotter indicates in his critical apparatus, there seems to be some disagreement about the term $\Sigma \chi \eta \mu \alpha \tau \iota \kappa o$. Three manuscript traditions offer a form of "schismatics", suggesting that these Egyptians were separated by ecclesial politics more than by ideology ${ }^{16}$. Another explanation is that $\Sigma \chi \eta \mu \alpha \tau \iota \kappa o$ was a specific name applied to the Monophysites, implying that they espouse a form of Docetism since they claim that Christ's humanity is little more than an illusion ${ }^{17}$. A third possibility is that the term is simply another label for heretics ${ }^{18}$. In any case, $\Sigma \chi \eta \mu \alpha \tau \imath$ koí underscores the ambiguities in the treatment of Monophysitism in the De haeresibus. Damascenus lists the disciples of Dioscorus, the Theodosians, and the Jacobites as examples of Egyptians who all espoused Monophysitism in one sense or another, since all shared an attraction for Dioscorus and by extension to Eutyches ${ }^{19}$. He also includes in his list the heretics Severus of Antioch and "John the Tritheist" (John Philoponus). As is clear with the Jacobites and the final heretics listed, John Damascene's understanding of Egyptians includes Christians outside of Egypt as well, people who shared neither language nor location ${ }^{20}$. As De haeresibus 83 indicates, Damascenus' views on Monophysitism are not always straightforward. On the one hand he uses the rhetorical language of proChalcedonians of the preceding centuries and introduces Monophysitism as a heresy alongside Nestorianism and Eutychianism; on the other, he is willing to distinguish between different levels of Monophysitism. To understand this text more clearly, we need to look at what Damascenus says on the subject in his other writings.

For the Contra Jacobitas I will consider two aspects of John's argument against Monophysites: first will be his general attitude of Monophysitism, second will be how he uses the terms "orthodoxy" and $\mu$ í $\alpha$ pvoเs, terms which illustrate his attitude. The Contra Jacobitas begins with a brief history of the controversies that led to the more precise Christological language of later centuries. This list includes the heretics Arius, Eunomius, Sabellius, Nestorius, Diodore of Tarsus, Theodore of Mopsuestia, Dioscorus, and Severus

${ }^{16}$ Cf. Die Schriften des Johannes von Damaskos, vol. 4, ed. Kotter, p. 49n. This is apparently the view of Chase (Saint John of Damascus, Writings, p. 138, n. 64), though the translation follows PG 94, 741A. Kotter lists two variants, apparently omitting the third instance found in Paris grec. 1320 ff. 247r-263v (=B. Kotter 484, U). A fourth manuscript, Paris Coislin 34 ff. 190v-200r (=B. Kotter 506, S), which uses Schematikoi, also provides Eutychianitai, so its preference for Schematikoi is less informative.

${ }^{17}$ This is the opinion of G.W.H. Lampe at least (Lampe 1359-1360). On this, cf. Louth, St. John Damascene, p. 157.

${ }^{18}$ This option is proposed by Louth, St. John Damascene, p. 158.

${ }^{19}$ Cf. Johannes Damascenus, Liber de haeresibus 83, 10, PTS 22, 49, transl. Chase, p. 139.

${ }^{20}$ There is evidence that Coptic Christians were called Jacobites at times, though the Jacobites themselves were largely responsible for this practice in later times. Cf. S. Griffith, Byzantium and the Christians in the World of Islam: Constantinople and the Church in the Holy Land in the Ninth Century, "Medieval Encounters" 3 (1997) 264 n. 149. 
of Antioch. These controversies collectively determined the meaning of the

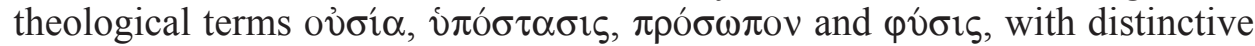
implications for Christian worship. The historical narrative provided is only cursory, but Damascenus' purpose is to introduce his theological arguments and a subtle understanding of history is unnecessary here. Notably absent in his history is any reference to the councils, particularly Chalcedon, which he includes in De haeresibus 83. Damascenus lays out his intentions in Contra Jacobitas 4, introducing his theology - in line with Chalcedonian orthodoxy - as a "royal middle way" between two sets of erroneous beliefs ${ }^{21}$. John criticizes Monophysitism and Nestorianism as combating one error with another; instead, his approach will be as a mean between the two evils, somewhere within the confines of truth ${ }^{22}$.

Orthodoxy appears in Liber de haeresibus 83, when Damascenus calls mainstream Christians "orthodox" as opposed to the non-Chalcedonian Egyptians. He also applies the term "orthodox" to (most of) the Egyptian teachings, apart from their rejection of Chalcedon. In the De haeresibus, orthodoxy serves primarily to distinguish between those who accept Chalcedon's authority and those who reject the same. In the Contra Jacobitas, John Damascene uses "orthodox" when referring to Christian doctrine, especially as it pertains to Christ's natures. In Contra Jacobitas 55, he asks what authority would appeal to both those who confess a single nature in Christ and those who profess Christ's

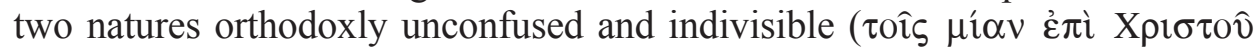

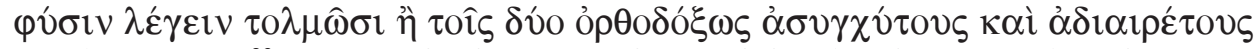

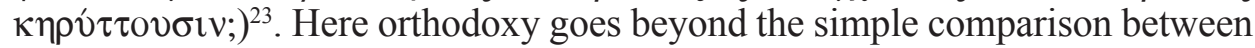
mainstream Christianity and the Monophysites: it is used to express the correct way to explain the relationship between Christ's two natures.

The term "orthodoxy" appears in two other important places in the Contra Jacobitas $^{24}$. The first is in Contra Jacobitas 81, in which Damascenus makes a comparison between the dyophysite Christological teachings of Nestorius, the "God-despising" ( $\theta \varepsilon \circ \sigma \tau v \gamma \eta ́$ ) bishop - who preached that Christ's union was not hypostatic and was according to dignity or a sameness in the will, name, or honor - and the Chalcedonian Christological teachings, orthodoxly taught as a true union that occurs hypostatically. In this case, Chalcedonian Christians and Nestorius agree in their doctrine of two natures in Christ, but they differ in their descriptions of the relationship between the two natures. As in chapter 55, orthodoxy in chapter 81 refers to the way that the dyophysite doctrine is explained and does not necessarily imply a whole-hearted rejection

${ }^{21}$ Johannes Damascenus, Contra Jacobitas 3, 4, ed. B. Kotter, PTS 22, 111, transl. Louth, St. John Damascene, p. 180.

${ }^{22}$ Cf. ibidem 3, 6-7, PTS 22, 111.

${ }^{23}$ Ibidem 55, 11-13, PTS 22, 129.

${ }^{24}$ It appears in a fourth location, Contra Jacobitas 115, 9, but it falls within the florilegium appended to the end. 
of the teaching. Contra Jacobitas 88 concludes the main text of the Contra Jacobitas before the appended florilegium. In this chapter, Damascenus provides a brief doxological statement about the Holy Trinity and about the incarnate second Person, as it has been stated by the Holy Fathers. He states that their doctrine of the one divine nature in the Trinitarian $v \pi \circ \sigma \tau \alpha$ c $\sigma \varepsilon ı \varsigma$ and one i ó$^{-} \tau \alpha \sigma i \varsigma$ of the second Person in two natures without confusion and without

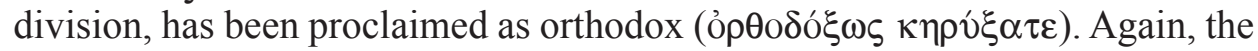
emphasis here is not simply on the terms involved, but on the limitations that have been added to them as well. It is not enough to use the proper language, but that language must be correctly understood as well.

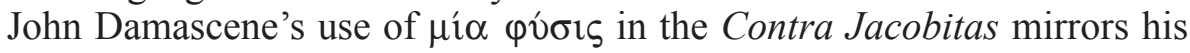
use of orthodoxy. While he criticizes the Monophysites, he does not reject their teachings outright. For example, in Contra Jacobitas 55 he addresses both the orthodox and the Monophysites, seeking a common theological authority between them. Damascenus appeals to St. Gregory the Theologian as the shared authority, who had addressed Christ's two (i.e., divine and human) natures in his Epistle $101^{25}$. In the same chapter, explicating a passage from Theodoret (falsely attributed to St. Justin Martyr), he points out the statement that a human being "has two natures" 26 and he is "not one human nature out of two natures" 27 . If an ordinary human person retains two natures, then all the more would Christ also have two natures. One of the difficulties in the postChalcedonian debates flows from Christian metaphysics concerning natures and $\dot{\pi} \pi \circ \sigma \tau \alpha \dot{\sigma} \sigma \varepsilon ı$. A key figure in this movement was the Monophysite John Philoponus, who strongly emphasized the importance of particular natures, inherent in individuals ${ }^{28}$. While we can speak about human nature, we most properly speak about human nature as it is present in the individual. The same can be said about Christ. Philoponus explains,

"In this meaning of «nature», «hypostasis» and «nature» are, as it were, the same, except that the term «hypostasis» in addition also signifies those properties which, apart from the common nature, belong to each of the individuals, and by which they are separated from each other"29.

A significant problem with Philoponus's metaphysics is its implications in Trinitarian theology: if each vं ó$_{\tau} \tau \alpha \sigma \iota \varsigma$ implies a nature, then there will inevitably be three divine natures. John of Damascus enters into this debate, acknowledging

${ }^{25}$ Cf. ibidem 55, 11-14. Gregory's Epistle 101 is addressed to Cleodinus and aims to refute Apollinaris' teachings.

${ }^{26}$ Johannes Damascenus, Contra Jacobitas 54, 12, PTS 22, 128.

${ }^{27}$ Ibidem 55, 1-2, PTS 22, 129.

${ }^{28}$ Cf. U.M. Lang, The Controversies over Chalcedon and the Beginnings of Scholastic Theology: The Case of John Philoponus, in: The Mystery of Christ in the Fathers of the Church: Essays in Honour of D. Vincent Twomey SVD, ed. J.E. Rutherford - D. Woods, Dublin 2012, 78-93.

${ }^{29}$ Johannes Philoponus, Arbiter 7, 23, 22, 21-24, transl. Lang, The Controversies over Chalcedon, p. 85. 
the deficiency in pro-Chalcedonian metaphysics. He agrees with Philoponus's general ideas concerning nature and individual, but he makes some clear modifications for the instantiations of Christ's natures. While the $\Lambda$ ó $\gamma$ os is and has eter-

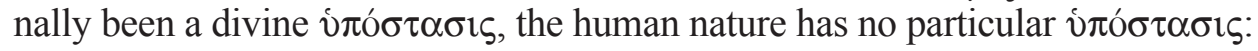

"We call [his human nature] enhypostatic because it does not exist on its own nor does it have its own proper hypostasis, but it exists within the hypostasis of the Word" ${ }^{30}$.

In this text Damascenus demonstrates that the Monophysite rejoinder to Chalcedon has merit and needs to be addressed. Along these lines he adopts Cyril's

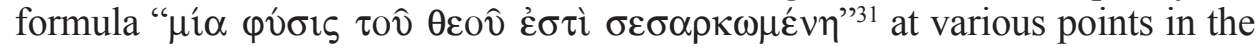
Contra Jacobitas. In the first such instance, Damascenus calls Cyril's formula a common belief of both Monophysites and mainstream Christians, since it comes from the Church Fathers. He even tells the Jacobites that if they want to explain the two natures through the Cyrillean phrase, then it is absurd to quibble over the truth ${ }^{32}$. Another time Damascenus invokes Cyril's formula, he notes an inconsistency between calling the Word incarnate and denying the two natures of Christ; anyone who says the Word takes on flesh either denies his incarnate power or speaks around the two natures anyway ${ }^{33}$. He uses the Monophysite phrase to push back against the distinction the Monophysites themselves want to keep. Damascenus implies that the separation between the Monophysites and orthodox Christians is in attitude and politics much more than in reality. However, he is not making an idle claim; his ability to assert such congruence

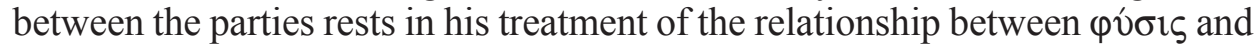
vंó $\sigma \tau \alpha \sigma ı \varsigma$, which appears at various points in the Contra Jacobitas ${ }^{34}$.

While the Contra Jacobitas might come across as congenial, the Contra Nestorianos presents a much harsher judgment against the Nestorians, particularly their namesake, Nestorius. John Damascene demonstrates little of the middle way present in his Contra Jacobitas, but devotes most of the text to combating Nestorianism. Damascene even calls Nestorius a „God-killer”

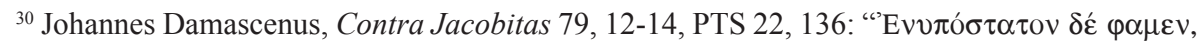

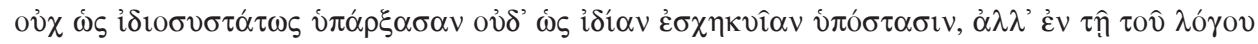

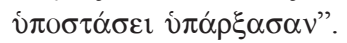

${ }^{31}$ Cf. ibidem 52, 1, PTS 22, 125; ibidem 58, 1, ed. Kotter, p. 130.

${ }^{32}$ Cf. ibidem 52, 2-4, PTS 22, 125-126.

${ }^{33}$ Cf. ibidem 68, 1-3, PTS 22, 132.

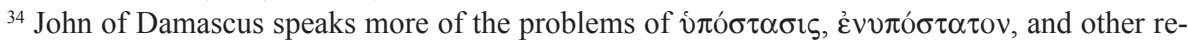
lated terms in his Dialectica (cf. Johannes Damascenus, Dialectica, in: Die Schriften des Johannes des Damaskus, vol. 1: Institutio elementaris. Capita philosophica (Dialectica), ed. B. Kotter, PTS 7, Berlin 1969, 47-145, transl. F.H. Chase, Jr.: Saint John of Damascus, Writings, The Fathers of the Church: A New Translation 37, Washington 1958, 5-110) and again in the Expositio fidei (cf. idem, Expositio fidei, in: Die Schriften des Johannes des Damaskus, vol. 2: Expositio fidei, ed. B. Kotter, PTS 12, Berlin 1973, 7-239, transl. F.H. Chase, Jr.: Saint John of Damascus, Writings, The Fathers of the Church: A New Translation 37, Washington 1958, 163-406. 
$(\theta \varepsilon \dot{\omega} \lambda \eta \varsigma)$ in the work ${ }^{35}$. This attitude is more surprising if we consider that Nestorius's name does not appear in any of the eight Eastern synods convened between 486 and $612^{36}$. Moreover, where the Contra Jacobitas begins with a historical account of Monophysitism, the Contra Nestorianos begins with a question directed to those who agree with Nestorius:

"Whom did the Holy Virgin conceive at the Annunciation, the one who was Son of God and God by nature or simply a man?"37

The only use of orthodox in the work is found in the first given answer to this question. If a so-called Nestorian should respond that the Holy Virgin conceived of the one who is God by nature, then that one is orthodox. If another response is given, then Damascenus has a series of questions addressing the various conceivable answers the Nestorians might provide.

Though John of Damascus uses orthodox only once in the Contra Nesto-

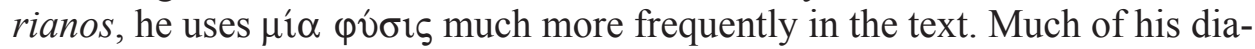
logue centers on the distinction between the unity found in God (three Persons in one nature) and Christ (one person in two natures). At one point he argues that if the Trinity were united in all things except hypostasis, though the incarnation took place through relationship and operation, then the Father and the Holy Spirit would be equally united to the incarnate one ${ }^{38}$. In the last chapter Damascenus revisits his teachings from throughout the work and here invokes Cyril's phrase for Christ's incarnation. He writes:

"He is both the very one and the same, truly perfect God and by nature incorrupt, perfect man, one hypostasis in two indivisible natures. [...] We teach one incarnate nature of the incarnate Word of God. We know and profess that the one who is by nature the Son of God and God had two generations, one incorporeal and uncaused from the father before the ages, and one corporeal and temporal from the Holy Virgin, in the last time for our salvation made flesh and become man"39.

Even while Damascenus pronounces Chalcedonian orthodoxy over Nestorianism and leaves little room for dialogue between the two, he simultaneously invokes the Cyrillean formula of the one incarnate nature. The result is that in both the Contra Nestorianos and the Contra Jacobitas he presents much harsher language against the Nestorians than he does against the Monophysites.

There are several likely reasons for John Damascene's attitude, which we can see from the Contra Nestorianos. First is the problem of Biblical interpretation. All through the Contra Nestorianos Damascenus provides passages on

\footnotetext{
${ }^{35}$ Cf. Johannes Damascenus, Contra Nestorianos 43, 62, ed. B. Kotter, PTS 22, 288.

${ }^{36}$ Cf. Brock, The "Nestorian" Church, p. 29.

37 Johannes Damascenus, Contra Nestorianos 1, 2-3, PTS 22, 263.

${ }^{38}$ Cf. ibidem 21, PTS 22, 270-271.

${ }^{39}$ Ibidem 43, 48-49. 53-58, PTS 22, 287.
} 
Christ's person, natures, and incarnation. He includes the typical New Testament verses such as the Prologue to John's Gospel ${ }^{40}$ and The Bread of Life Discourse $^{41}$, or the Epistles to the Hebrews and to the Ephesians ${ }^{42}$, as well as the Old Testament prophecies and allegories to Christ ${ }^{43}$. If Christ is not a single subject, then how are the verses to be understood? While it is certainly plausible that Damascenus considered the interpretation of Scripture a good to be safeguarded, we are still left with the problem of why he would think his project necessary if no true Nestorians were around to make such a claim. A more plausible motive is that he felt compelled to distance his own writings from Nestorianism. By the eighth century, Monophysites would deride orthodox Christians as Nestorians because of their emphasis on Christ's two natures ${ }^{44}$. It was necessary, therefore, that Damascenus attack the Nestorian position in order to demonstrate that he was not a Nestorian himself. Again, this concern is reflected in his writings. In the Contra Nestorianos, he avoids discussion of the Monophysites. Furthermore, he includes the Cyrillean formula in his statement of orthodox doctrine ${ }^{45}$.

Let us return to where we began, chapters 81 and 83 of the Liber de haeresibus. How are we to understand John Damascene's description of the Nestorians and the Egyptians? It seems that he addresses Nestorianism in general rather than a specific group of Nestorians. He recognizes some important elements in Nestorian theology, specifically the divine nature's transcendence ${ }^{46}$, but most of his work is meant to refute Nestorian beliefs. Yet it is probably best to see Damascenus' condemnation of Nestorianism in the De haeresibus as a line drawn in the sand between his orthodoxy and Nestorianism in partial response to Monophysite accusations. Chapter 83 is more difficult to explain. It seems as though Damascenus is hedging his bets against Monophysitism. His decision is all the more apparent in light of the earlier conflation of these theologies, as Pope St. Leo the Great and others had done. Perhaps Damascenus' decision reflects an understanding that some texts that serve as the foundation of Monophysitism, such as Cyril's works, are likewise important for general orthodox Christianity and these texts cannot be dismissed outright. Furthermore, there is likely a possibility of unity between Monophysite teachings and orthodox teachings, so Damascenus focuses on the errors of their chief theologians. If their theology is not entirely different, then the problem resides in some sort of politics; they exist in schism from each other. At the same time, he admits possible theological conflict between Monophysitism

\footnotetext{
${ }^{40}$ Cf. ibidem 42, 23-37, PTS 22, 281.

${ }^{41}$ Cf. ibidem 42, 56-68, PTS 22, 282.

${ }^{42}$ Cf. ibidem 40, 1-3 PTS 22, 278-279; ibidem 41, PTS 22, 279-280.

${ }^{43}$ Cf. ibidem 42, 3-18, PTS 22, 280-281.

${ }^{44}$ Cf. Griffith, "Melkites", "Jacobites", and the Christological Controversies, p. 36.

${ }^{45}$ Cf. Johannes Damascenus, Contra Nestorianos 43, 53-54, PTS 22, 287.

${ }^{46}$ Cf. Louth, St. John Damascene, p. 173.
} 
and Chalcedonian orthodoxy, as demonstrated by the included selections from the Arbiter. Thus it is that even in the context of a panoply of heresies, John of Damascus leaves the distinction between heresy and schism undetermined, perhaps laying the verdict in the hands of those whom he addresses.

\section{(Summary)}

St. John Damascene's writings on heresies - specifically those texts against Nestorianism and Monophysitism - demonstrate a careful consideration of how thin the line is between schism and heresy. In the texts on heresies, Damascenus endeavors to reread the separation of certain Churches as an ecclesial problem and not only a theological problem. His writings blur the lines between heresy, normally a theological concern, and schism, an ecclesiastical term normally reserved for the separation of Christian Churches.

St. John Damascene's teachings against heresies fit well within the culture of florilegia and compilations. John's goal, particularly in the De haeresibus, seems to have been to contribute scholarly to the growing world of anti-heretical texts. His texts add to the already large list of known heresies, registering heresies that arose after the council of Chalcedon.

Yet John's texts against heresies are not meant simply to combat false teachings. In some cases, particularly Monophysitism, Damascenus contends that the terms used by orthodox (pro-Chalcedonian) Christians and Monophysite Christians mean the same thing. We must read the Liber de haeresibus in the context of his other writings (e.g. Contra Jacobitas or Contra Nestorianos) in order to determine his true purpose. These definitions aim not to divide Christians based only on teachings, but to show the common understanding present in Christology in spite of different vocabulary. With a proper understanding of heresy, John of Damascus is able to provide a more complete description of the schisms in the Church of his time.

\section{JAN DAMASCEŃSKI O HEREZJI I SCHIZMIE: REINTERPRETACJA POJĘĆ}

\section{(Streszczenie)}

Pisma św. Jana Damasceńskiego dotyczące herezji, a konkretnie teksty przeciwko nestorianom i monofizytom, wykazuja staranne przemyślenia, jak cienka jest linia między schizmą i herezją. W tekstach o herezjach, Damasceńczyk stara się odczytać na nowo oddzielenie się niektórych Kościołów jako problem eklezjalny, a nie tylko teologiczny. Jego pisma zamazują granicę między herezją - normalnie pojęciem teologicznym, a schizma - kościelnym terminem zarezerwowanym powszechnie do faktu oddzielenia się od Kościołów chrześcijańskich. Nauczanie Jana Damasceńskiego przeciw herezjom odpowiada dobrze kulturze 
florilegiów i kompilacji. Wydaje się, że celem Jana, zwłaszcza w traktacie $D e$ haeresibus, jest przyczynić się naukowo w rosnącym świecie antyheretyckich tekstów. Jego pisma dodają do szerokiej listy znanych już herezji, także te, które powstały po Soborze Chalcedońskim.

Jednak teksty Jana przeciw herezjom nie są przeznaczone jedynie do zwalczania fałszywych nauk. W niektórych przypadkach, zwłaszcza monofizytyzmu, Damasceńczyk twierdzi, że terminy używane przez ortodoksyjnych (pro-chalcedońskich) i monofizyckich chrześcijan oznaczają to samo. Trzeba czytać Liber de haeresibus w kontekście innych jego pism (np. Contra Jacobitas lub Contra Nestorianos), by określić jego prawdziwy cel. Terminy te mają na celu nie dzielić chrześcijan, bazując tylko na nauczaniu, ale pokazać wzajemne rozumienie obecne w chrystologii, mimo różnego słownictwa. $Z$ właściwym rozumieniem herezji, Jan z Damaszku, jest w stanie zapewnić pełniejszy opis schizm w Kościele swej epoki.

Key words: John of Damascus, heresy, schism.

Slowa kluczowe: Jan z Damaszku, herezja, schizma.

\section{BIBLIOGRAPHY}

\section{Sources}

Johannes Damascenus, Contra Jacobitas, ed. B. Kotter, in: Die Schriften des Johannes von Damaskos, vol. 4: Liber de haeresibus. Opera polemica, PTS 22, Berlin 1981, 109-153. Johannes Damascenus, Contra Nestorianos, ed. B. Kotter, in: Die Schriften des Johannes von Damaskos, vol. 4: Liber de haeresibus. Opera polemica, PTS 22, Berlin 1981, 256-288.

Johannes Damascenus, Liber de haeresibus, ed. B. Kotter, in: Die Schriften des Johannes von Damaskos, vol. 4: Liber de haeresibus. Opera polemica, PTS 22, Berlin 1981, 1-67, transl. F.H. Chase, Jr.: Saint John of Damascus, Writings, The Fathers of the Church: A New Translation 37, Washington 1958, 111-163.

\section{Literature}

Bвоск S., The "Nestorian" Church: A Lamentable Misnomer, "Bulletin of the John Rylands Library" 78 (1996) fasc. 3, 23-35.

Brock S., The Syriac Churches and Dialogue with the Catholic Church, "Heythrop Journal" 45 (2004) 466-476.

Cameron A., How to Read Heresiology, "Journal of Medieval and Early Modern Studies" 33 (2003) 471-492.

Griffith S., Byzantium and the Christians in the World of Islam: Constantinople and the Church in the Holy Land in the Ninth Century, "Medieval Encounters" 3 (1997) 231-265.

Griffitr S., John of Damascus and the Church in Syria in the Umayyad Era: The Intellectual and Cultural Milieu of Orthodox Christians in the World of Islam, "Hugoye: Journal of Syriac Studies" 11 (2008) fasc. 2, 207-237.

Griffith S., "Melkites", "Jacobites", and the Christological Controversies in Arabic in Third/Ninth Century Syria, in: Syrian Christians Under Islam: The First Thousand Years, ed. D. Thomas, Leiden 2001, 9-55. 
Grillmeier A., Christ in Christian Tradition, vol. 2: From the Council of Chalcedon (451) to Gregory the Great (590-604), pt. 4: The Church of Alexandria with Nubia and Ethiopia after 451, transl. O.C. Dean, Jr., London 1996.

KNORR O., Zur Überlieferungsgeschichte des "Liber de haeresibus" des Johannes von Damaskus (um 650-vor 754): Anmerkungen zur Edition B. Kotters, ByZ 91 (1997) 59-69.

LANG U.M., The Controversies over Chalcedon and the Beginnings of Scholastic Theology: The Case of John Philoponus, in: The Mystery of Christ in the Fathers of the Church: Essays in Honour of D. Vincent Twomey SVD, ed. J.E. Rutherford - D. Woods, Dublin 2012, 78-93.

Louth A., St. John Damascene: Tradition and Originality in Byzantine Theology, Oxford 2002. 